\title{
X-RAY ANALYSIS OF BIOMASS WOOD BRIQUETTE STRUCTURE
}

\author{
Kamil Krzysztof Roman ${ }^{\mathrm{a}^{*}}$, Adam Świętochowski ${ }^{\mathrm{b}}$ \\ ${ }^{\text {a }}$ Institute of Technology and Life Sciences in Warsaw \\ ${ }^{\mathrm{b}}$ Department of Agricultural and Forest Machinery, Warsaw University of Life Sciences \\ *Corresponding author: email: k.roman@itep.edu.pl
}

\begin{tabular}{|c|c|}
\hline ARTICLE INFO & ABSTRACT \\
\hline $\begin{array}{l}\text { Article history: } \\
\text { Received: November } 2015 \\
\text { Received in the revised form: } \\
\text { December } 2015 \\
\text { Accepted: January } 2016\end{array}$ & $\begin{array}{l}\text { The study aims to measure the wood chips flow during the briquetting } \\
\text { process by the X-ray image analysis. Scots pine (Pinus sylvestris L.) } \\
\text { constituted the used feedstock that has been previously divided, } \\
\text { according to the standard, into four ( }>1.0 ; 1.1-4.0 ; 4.1-8.0 ; 8.1-16.0 \\
\mathrm{~mm} \text { ) groups of fraction. Examination of the X-ray image allows }\end{array}$ \\
\hline $\begin{array}{l}\text { Key words: } \\
\text { briquetting, } \\
\text { wood chips, } \\
\text { biomass flow, } \\
\text { X-ray radiation }\end{array}$ & $\begin{array}{l}\text { briquetting process. The correlations between the vertical axis and } \\
\text { scattering plane factors were estimated. The correlation coefficient } \\
\text { was } 0.973 \text { and was almost complete. The calculations were made for } \\
\text { the areas of deviations }\left(\mathrm{S}_{\mathrm{D}}\right) \text { and the area of scattering planes }\left(\mathrm{D}_{\mathrm{PS}}\right) \text {. } \\
\text { Particular flow irregularities were determined for deviations ranges of } \\
\text { individual groups of fractions and were }(>1.0)=3.04 ;(1.1-4.0)=4.08 \text {; } \\
(4.1-8.0)=6.33 \text { and }(8.1-16.0)=7.33 \mathrm{~cm}^{2} \text {, and for scattering planes they } \\
\text { were accordingly e }(>1.0)=0.32 ;(1.1-4.0)=0.72 ;(4.1-8.0)=0.97 \text { and } \\
(8.1-16.0)=1.29 \mathrm{~cm}^{2} \text {. }\end{array}$ \\
\hline
\end{tabular}

\section{Introduction}

$\mathrm{X}$-ray radiation is an electromagnetic field that is generated during the electron relaxation. The wave latitude measures $10 \mathrm{pm}$ to $10 \mathrm{~nm}$ and is placed between the ultraviolet (UV) and gamma radiation (L'Annunziata and Baradei, 2003). Techniques involving the $\mathrm{X}$-ray radiation are popular mainly in medicine to diagnose internal structure of objects (Ajaj and Ghassal, 2003). However, they are also used in defectoscopy (Matuchova et al., 2009) or structural studies and spectral analysis.

The X-ray diagnosis method is based on absorption of wave radiation by various particle matters. In softer matters X-ray waves with higher radiation intensity pass easier through the structure, making blackout spots on the photographic paper (Kastengren and Powell, 2014; Liu and Qiao, 2010). This process is caused by two electrodes (cathode and anode) sunk in a vacuum or in the compressed air in a glass bulb. A cathode when reaching the voltage of incandescence $U_{h}$ causes that electrons are emitted, that is accelerated by the anode voltage $U_{a}$. Electrons reaching the anode are detained by the matter (L'Annunziata and Baradei, 2003).

X-ray images of wood briquette were characterized. In special cases bulk material (Roman, 2015) is similar to the liquid medium, by the properties of the plastic flow (Horabik 
Kamil Krzysztof Roman, Adam Świętochowski

and Grochowicz, 2000). Hypothetically, when the speed of the piston displacement is significantly low, briquetting material can be determined by the polytropic equation (Skalweit, 1938). Interpretation of bulk material plastic flow can predict internal stuck or dead zones during the transport procedure, supporting the bioenergy generation for example in developing countries (Raslavičius et al., 2011).

The research aims to describe patterns that appeared after the briquetting process. Patterns were different for every individual group of briquetted fractions.

\section{Material and methods}

The research raw material was shredded by the RTB13 chopper. The chopper was equipped with a beater disc and a chopping unit. A shredder was equipped with a circular mesh screen with a diameter of $10 \mathrm{~mm}$.

Studies were carried out individually for Scots pine wood briquettes made of separated fraction groups that were divided on a sieve separator according to the standard PN-EN 15149-1:2011 and PN-EN 15149-2:2011. The research material was separated into 4 classes fraction lengths as $>1.0,1.1-4.0,4.1-8.0$ and $8.1-16.0 \mathrm{~mm}$.

The described method assumes the studies of compacting the wood material (Grzybek, 2004 ) in a specially prepared prototype tube. All calculations were made on the two dimensions. In the one-side closed tube of $45 \mathrm{~mm}$ diameter and $300 \mathrm{~mm}$ height, bulk materials were compacted under the pressure that reached $62 \mathrm{MPa}$. The movement speed of a punch was $2.5 \mathrm{~mm} \cdot \mathrm{s}^{-1}$ in a die that was heated to the temperature of $80^{\circ} \mathrm{C}$. The pressure needed for compression could deform a pore affecting the density change of bulk material (Lisowski et al., 2014, Nurek and Roman, 2014).

The size of a fraction was purposefully selected (Skonecki and Laskowski, 2010) to initiate and observe the laminar and turbulent behaviour of the matter flow. It was noticed that the fraction size also effect the durability of the compressed structure (Lisowski and Świętochowski, 2014; Świętochowski, 2013). The studies include verification of the valid tests numbers, arithmetic mean, minimum, maximum and standard deviations. The statistical analysis also included the correlations of the material flow with the scattering plane. Statistica 10 software was used for statistical analysis.

The research focuses on the evaluation of the internal tube bulk material transport properties with the use of X-ray. To perform the X-ray image, Siemens Axiom Artis FC equipment was applied. Before briquetting, the bulk material was separated into four groups of fraction. According to the hypothesis, the flow of the briquetting material was closely related to the plane, individually for the four groups of fractions. X-ray images of wood biomass briquette were shown in the figure 1 .

The X-ray image was analysed in the specially prepared computer graphical program that was written in Delphi 7. The written program allows placing the lines and points on the $\mathrm{X}$-ray image mapping the movement of the material layers in the die during thickening, storing them in vectors to identify mutual positions. The image delivered information on characteristic patterns separately for each group of fraction. An individual pattern reflects the flow with internal and external friction. The studies were conducted in the cylindrical tube to keep the same coefficient of friction for each sample. 
X-ray analysis...

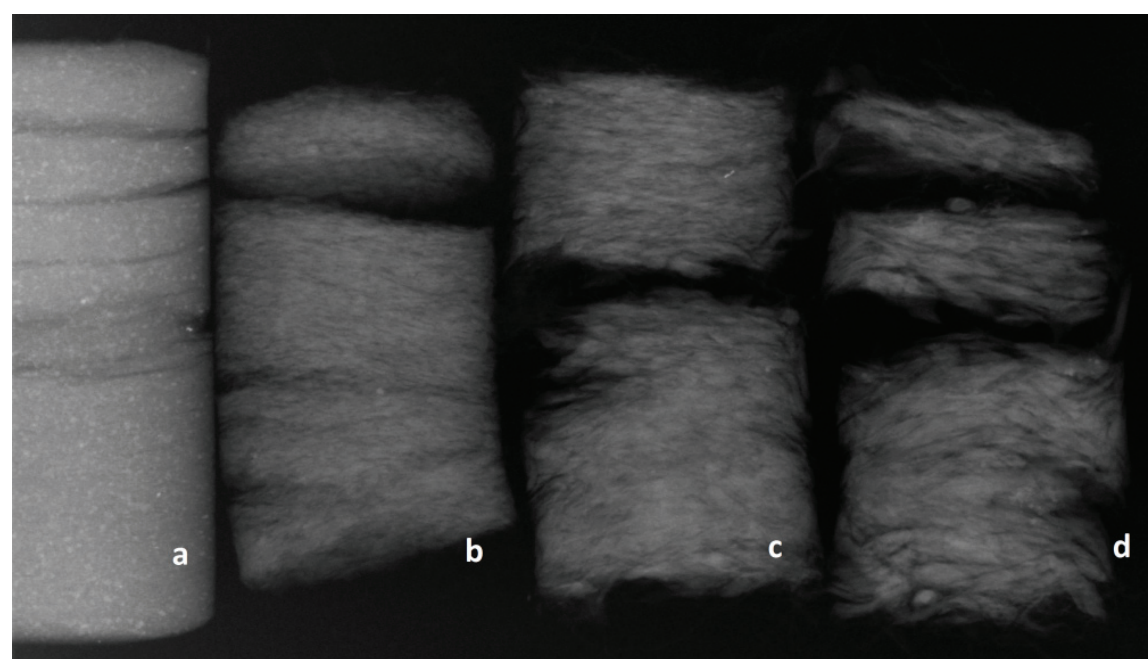

Figure 1. X-ray image of wood briquettes made of groups of fractions: a) >1.0 b)1.1-4.0 c) $4.1-8.0$ d) $8.1-16.0$

\section{Results}

Characteristics of area deviations during the flow for an individual fraction were determined. The X-ray image captured the post-briquetting fractions flow in the briquette structure. Characterized the patterns in which the borders were set by the vertical and horizontal axis. Tests were taken in a few spots and delivered as arithmetic means. The scattering plane distances from the vertical and horizontal axis for the fraction flow were determined during the analyses. Characteristics of the pattern distance arithmetic mean for an individual fraction were shown in table 1.

Table 1.

Characteristic of distance mean from axis and scattering plane in briquette for individual fraction group

\begin{tabular}{lccc}
\hline $\begin{array}{l}\text { Fraction } \\
(\mathrm{mm})\end{array}$ & $\begin{array}{c}\text { Distance from } \\
\text { vertical axis }(\mathrm{cm})\end{array}$ & $\begin{array}{c}\text { Distance from } \\
\text { horizontal axis }(\mathrm{cm})\end{array}$ & $\begin{array}{c}\text { Plane scattering } \\
(\mathrm{cm})\end{array}$ \\
\hline$>1.0$ & 0.85 & 2.25 & 0.09 \\
$1.1-4.0$ & 1.14 & 2.25 & 0.20 \\
$4.1-8.0$ & 1.77 & 2.25 & 0.27 \\
$8.1-16.0$ & 2.05 & 2.25 & 0.36 \\
\hline
\end{tabular}

The obtained data were subjected to the statistical analysis. The basic statistical analysis of the flow pattern mean for the individual group of fraction was shown in table 2. 
Kamil Krzysztof Roman, Adam Świętochowski

Table 2.

The basic statistical studies of distance from vertical axis and plane scattering factors

\begin{tabular}{lccccc}
\hline Factor & $\begin{array}{c}\text { Valid tests } \\
\text { numbers N }\end{array}$ & $\begin{array}{c}\text { Mean } \\
(\mathrm{cm})\end{array}$ & $\begin{array}{c}\text { Min } \\
(\mathrm{cm})\end{array}$ & $\begin{array}{c}\text { Max } \\
(\mathrm{cm})\end{array}$ & $\begin{array}{c}\mathrm{S}_{\mathrm{D}} \\
(\mathrm{cm})\end{array}$ \\
\hline Distance from vertical axis $(\mathrm{cm})$ & 4 & 1.45 & 0.85 & 2.05 & 0.55 \\
Plane scattering $(\mathrm{cm})$ & 4 & 0.23 & 0.09 & 0.36 & 0.11 \\
\hline
\end{tabular}

The correlation coefficient between the vertical axis and plane scattering factors was equal to 0.973 , which according to the scale adopted by Stanisz (2006), made the correlation almost complete. Coefficient was estimated for the arithmetic mean results that were in the confidence interval equal to 0.95 . The correlation of distance from the vertical axis and scattering plane factors were characterized in figure 2.

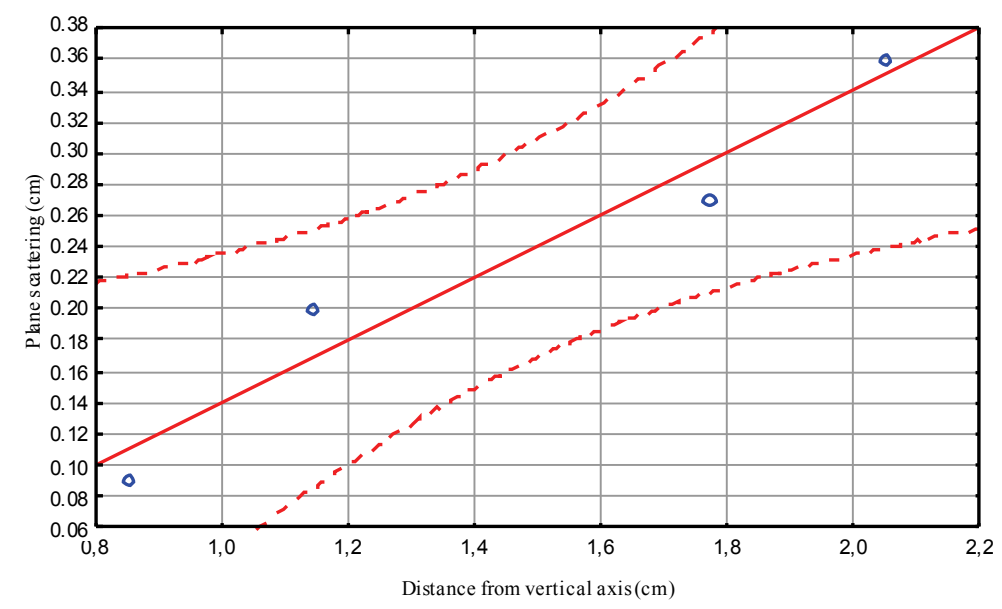

Figure 2. Correlation of vertical axis and scattering plane factors

During the material movement in the die, friction took place. It was reported, that the distance from the horizontal axis has a characteristic pattern of an elliptical shape. The length of the elliptical bow can be calculated by equation of elliptic integrals that has been shown in equation 1 .

$$
\frac{x^{2}}{r_{x}^{2}}+\frac{y^{2}}{r_{y}^{2}}=1
$$

where:
$x, y$ - coordinates of the point on the circumference of the ellipse,
$r_{x} \quad$ - radius of the horizontal axis OX,
$r_{y} \quad-$ radius of the vertical axis OY. 
X-ray analysis...

To determine the visual surface of changes, the equation should be transformed to the form 2 .

$$
y=\sqrt{\frac{r_{x}^{2} r_{y}^{2}-r_{y}^{2} x^{2}}{r_{x}^{2}}}
$$

During the calculations of the function the scattering plane for every group of fraction was also assumed. The function shows the occurring dependence between distances from the vertical to horizontal axis. The summary characterized every individual group of fractions. Figure 3 presents the diagram of distances from the vertical and horizontal axis.

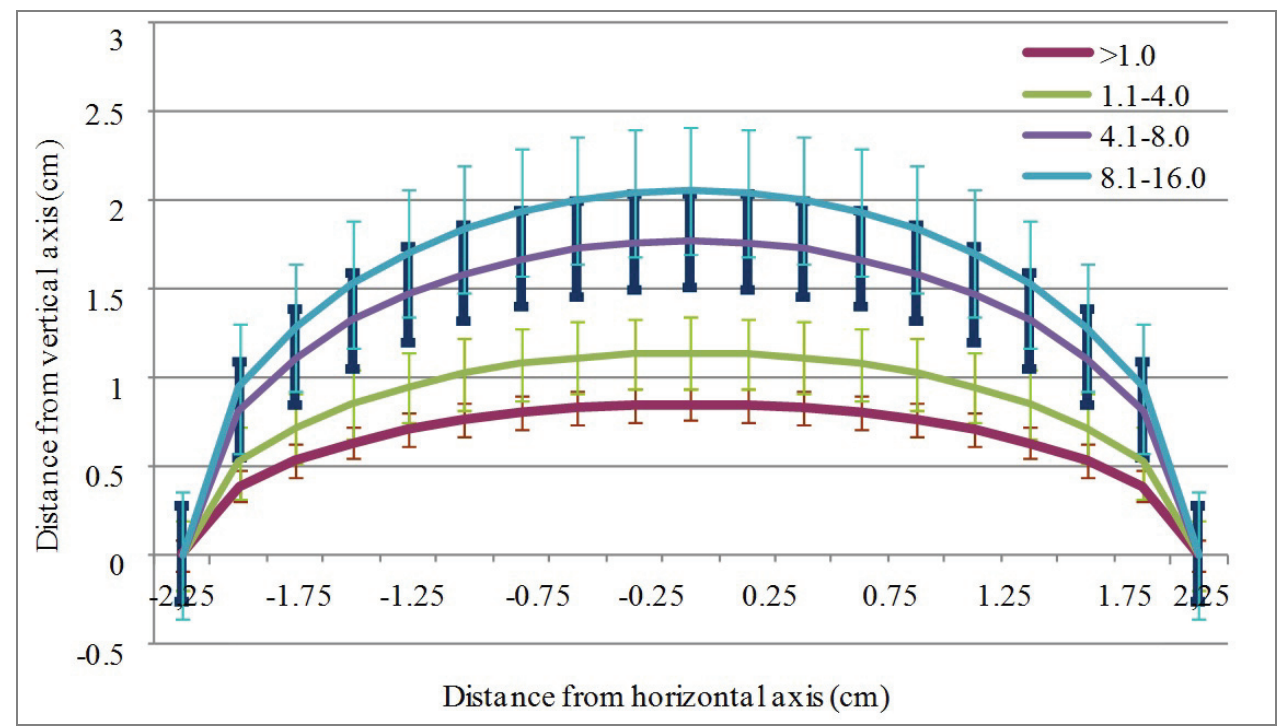

Figure 3. The distances from vertical and horizontal axis

Bends were individual for every group of fraction. The area of changes was placed below the functions. Internal deviations could be determined by an integral equation, taking into account the length of the horizontal diameter and the distance from the vertical axis. Calculation determines the area of deviations $\left(\mathrm{S}_{\mathrm{D}}\right)$ that was shown in equation 3 .

$$
S_{D}=\int_{-r_{x}}^{r_{x}} \sqrt{\frac{\mathrm{r}_{\mathrm{x}}^{2} \mathrm{r}_{\mathrm{y}}^{2}-\mathrm{r}_{\mathrm{y}}^{2} \mathrm{x}^{2}}{\mathrm{r}_{\mathrm{x}}^{2}}} d x
$$

The calculations of area where the deviations are made $\left(S_{D}\right)$ were bordered by the function and the horizontal axis. The deviations areas for individual groups of fractions were $(>1.0)=3.04 ;(1.1-4.0)=4.08 ;(4.1-8.0)=6.33$ and $(8.1-16.0)=7.33 \mathrm{~cm}^{2}$.

The range of the plane scattering could be also determined by the integral equation. The calculations necessary for determination of the area of the scattering planes $\left(D_{P S}\right)$ were presented in equation 4. 


$$
D_{P S}=\int_{-r_{x}}^{r_{x}} \sqrt{\frac{\left.\left(\mathrm{r}_{\mathrm{x}}+h_{n}\right)^{2} \mathrm{r}_{\mathrm{y}}^{2}-\mathrm{r}_{\mathrm{y}}^{2} \mathrm{x}^{2}\right)}{\left(\mathrm{r}_{\mathrm{x}}+h_{n}\right)^{2}}+\frac{\left.\left(\mathrm{r}_{\mathrm{x}}+h_{n}\right)^{2} \mathrm{r}_{\mathrm{y}}^{2}-\mathrm{r}_{\mathrm{y}}^{2} \mathrm{x}^{2}\right)}{\left(\mathrm{r}_{\mathrm{x}}-h_{n}\right)^{2}}} d x
$$

where:

$h_{n} \quad$ - scattering plane for individual fraction.

The X-ray photography also determined the turbulent and laminar behaviour of the wood fraction. The scattering plane for individual groups of fractions was $0.09 ; 0.20 ; 0.27$; $0.36 \mathrm{~mm}$ of tolerance. The range of deviations could be determined by the integral equation which calculates the area of planes $\left(D_{P S}\right)$. The areas of scattering planes for every group of fractions were $1(>1.0)=0.32 ;(1.1-4.0)=0.72 ;(4.1-8.0)=0.97$ and $(8.1-16.0)=1.29 \mathrm{~cm}^{2}$.

\section{Conclusions}

1. In the literature there is no verification of works devoted to the flow of wood biomass briquetting process using X-ray analysis. We can find only the characteristics of solid wood as a way of non-destructive evaluation (Tomazello et al., 2008). Some studies contain measurements of wood density (Hervé et al., 2014).

2. The flow of the bulk material in special cases could be determined by polytropic equation which obeys the relation of the thermodynamic process (Skalweit 1938). According to the theory, the solid biomass flow can be determined by the formula $p v^{m}=$ constans. The band for individual groups of fractions $(>1.0,1.1-4.0,4.1-8.0$ and $8.1-16.0 \mathrm{~mm})$ were $0.85 ; 1.14 ; 1.77 ; 2.05 \mathrm{~mm}$ of tolerance.

3. Calculations of deviations areas $\left(S_{D}\right)$ were $(>1.0)=3.04 ;(1.1-4.0)=4.08 ;(4.1-8.0)=$ 6.33 and $(8.1-16.0)=7.33 \mathrm{~cm}^{2}$, for areas of scattering planes $\left(D_{P S}\right)$ was $(>1.0)=0.32$; $(1.1-4.0)=0.72 ;(4.1-8.0)=0.97$ and $(8.1-16.0)=1.29 \mathrm{~cm}^{2}$.

4. The statistical analysis determines the strongest correlation between the distance from the vertical axis and the scattering plane. The correlation coefficient was significantly high and it was $r=0.973$ for the studied arithmetic mean. During the basic statistical analysis 4 valid tests were carried out, where standard deviation for the distance from the vertical axis was equal to $0.55 \mathrm{~cm}$ and for the scattering plane $-0.11 \mathrm{~cm}$.

\section{References}

Ajaj, F., Ghassal, N. (2003). An MCNP-based model of a medical linear accelerator X-ray photon beam. Australasian Physical and Engineering Sciences in Medicine, 26(3), 140-144.

Grzybek, A. (2004). Biomass management on rural areas - actual state and perspectives. Inżynieria Rolnicza, 1(56), 115-125.

Hervé, V., Mothe, F., Freyburger, C., Gelhaye, E., Frey-Klett, P. (2014) Density mapping of decaying wood using X-ray computed tomography. International Biodeterioration \& Biodegradation 86, 358-363.

Horabik, J., Grochowicz, M. (2000). Determination the parameters of bulk raw food plastic flow. Acta Agrophysica, 37, 29-30.

Kastengren, A., Powell, C. (2014). Synchrotron X-ray techniques for fluid dynamics. Experiments in Fluids, 55(3), 1-15. 
X-ray analysis...

L'Annunziata, M., Baradei, M. (2003). Handbook of Radioactivity Analysis. Academic Press, ISBN $0124366031,58$.

Lisowski, A., Świętochowski, A., Szulc, K., Lenart, A. (2011). Density and porosity of the cut and ground material of energy plants. Annals of Warsaw University of Life Sciences, Agricultural and Forest Engineering, 58, 21-28.

Lisowski, A., Świętochowski, A. (2014). Mechanical durability of pellets and briquettes made from a miscanthus mixture without and with the separation of long particles. Polish Society of Agricultural Engineering, 1, 93-100.

Liu, J., Qiao E. (2010). A statistical study of the relation between soft X-ray excess and accretion disk. Science China Physics, Mechanics and Astronomy, 53(1),102-105.

Matuchova, M., Zdansky, K., Zavadil, J., Danilewsky, A., Maixner, J., Alexiev, D. (2009). Electrical, optical and structural properties of lead iodide. Journal of Materials Science: Materials in Electronics, 20(3), 289-294.

Nurek, T., Roman, K. (2014). Effect of matter content on specic density of forest biomass. Annals of Warsaw University of Life Sciences, Agricultural and Forest Engineering, 64, 109-116.

PN-EN 15149-1. (2011). Biopaliwa stałe - Oznaczenie rozkładu wielkości ziaren - Część 1: Metoda przesiewania oscylacyjnego przy użyciu sit o szczelinie $3,15 \mathrm{~mm}$ lub większej.

PN-EN 15149-2. (2011). Biopaliwa stałe - Oznaczenie rozkładu wielkości ziaren - Część 2: Metoda przesiewania wibracyjnego przy użyciu sit o szczelinie $3,15 \mathrm{~mm}$ lub mniejszej.

Raslavičius, L., Grzybek, A., Dubrovin, V. (2011). Bioenergy in Ukraine - Possibilities of rural development and opportunities for local communities. Energy Policy, 39(6), 3370-3379.

Roman, M. (2015) Compost heap in agrotourism farm as an example of the renewable source of energy, Economic and Regional Studies, 8(3), 123-130.

Skalweit, H. (1938). Kräfte und Beanspruchungen in Strohpressen. 4 Konstrukteur-Kursus. RKTL, $88,1-8$.

Skonecki, S., Laskowski, J. (2010). Wpływ wielkości cząstek rozdrobnionej pszenicy na parametry procesu zagęszczania. Inżynieria Rolnicza, 3(121), 185-191.

Stanisz, A. (2006). Przystępny kurs statystyki z zastosowaniem STATISTICA PL na przyktadach $z$ medycyny. Tom 1. Statystyki podstawowe, 532.

Świętochowski, A. (2013). Aglomeracja ciśnieniowa biomasy $i$ właściwości fizyczne paliw formowanych z roślin energetycznych. Doctoral dissertation, 165.

Tomazello, M., Brazolin, S., Chagas, M. P., Oliveira, J. T. S., Ballarin, A. W., Benjamin, C. A. (2008). Application of x-ray technique in nondestructive evaluation of eucalypt wood. Ciencia $y$ tecnología 10(2), 139-149. 
Kamil Krzysztof Roman, Adam Świętochowski

\section{ANALIZA STRUKTURY BRYKIETÓW DRZEWNYCH PRZY UŻYCIU PROMIENI RENTGENOWSKICH}

Streszczenie. Badania miały na celu określenie przepływu frakcji zrębków drzewnych w trakcie brykietowania wykorzystując analizę obrazu zarejestrowaną przy użyciu promieni rentgenowskich. Użytym materiałem była sosna zwyczajna, która uprzednio przygotowano w formie zrębków i sklasyfikowano według normy na czerech grupy frakcji (>1.0, 1.1-4.0, 4.1-8.0 i 8.1-16.0 mm). Analiza obrazu rentgenowskiego pozwoliła na charakterystykę ruchu frakcji surowca w trakcie procesu brykietowania. Zarejestrowany współczynnik korelacji pomiędzy osią pionową i płaszczyzną rozpraszania był prawie pełen i wynosił 0.973 . Wykonane obliczenia zostały przeprowadzone dla obszarów rozproszenia przepływu biomasy, na których występowały nieregularności przepływu $\left(\mathrm{S}_{\mathrm{D}}\right)$ i płaszczyzn charakteryzujących powierzchnie rozpraszania $\left(\mathrm{D}_{\mathrm{PS}}\right)$. Określone nieregularności przepływu oszacowano dla poszczególnych grup frakcji na poziomie $(>1.0)=3,04 ;(1.1-4.0)=4,08 ;(4.1-8.0)=6,33$ $\mathrm{i}(8.1-16.0)=7,33 \mathrm{~cm}^{2}$, zaś dla płaszczyzn rozproszenia wynosiły kolejno $(>1.0)=0,32 ;(1.1-4.0)=0,72$; $(4.1-8.0)=0,97 \mathrm{i}(8.1-16.0)=1,29 \mathrm{~cm}^{2}$.

Słowa kluczowe: brykietowanie, zrębki drzewne, przepływ biomasy, promieniowanie rentgenowskie 